\title{
The Effect of Different Ways in Presenting Teaching Materials on Students' Mathematical Problem Solving Abilities
}

\author{
Nenden Mutiara Sari \\ Universitas Pasundan, Indonesia, nenden.mutiara@unpas.ac.id \\ Poppy Yaniawati \\ Universitas Pasundan, Indonesia, pyaniawati@unpas.ac.id

\section{Darhim} \\ Universitas Pendidikan Indonesia, Indonesia, darhim@upi.edu

\section{Bana G. Kartasasmita} \\ Universitas Pasundan, Indonesia, bana.kartasasmita@gmail.com
}

This study aimed to investigate the effects of different ways of presenting teaching materials on enhancing mathematical problem-solving abilities. This research was obtained using a quasi-experimental design with the non-equivalent control group design. The study population was all eighth graders enrolled in public junior high schools (SMP) in the city of Cimahi, Indonesia. There are 11 schools in total. Stratified random sampling and random sampling group techniques were used to select nine groups from 3 school categories. The instruments used were instruments of mathematical problem-solving ability tests, and observation sheets. The first experimental group was given exploration teaching materials presented through the snow-cube throwing learning model. The second experimental group was given exploration teaching materials presented in sheets of paper. The control group was given expository learning without exploration teaching materials. Data on mathematical problem-solving abilities were collected using tests distributed before and after learning. Research data were analyzed using descriptive and inferential statistics. The results of the study show that the different ways of presenting teaching materials can have an impact on enhancing problem-solving abilities.

Keywords: snow-cube throwing learning model, exploration approach, problem-solving ability, teaching materials, student involvement

Citation: Sari, N. M., Yaniawati, P., Darhim, \& Kartasasmita, B. G. (2019). The Effect of Different Ways in Presenting Teaching Materials on Students' Mathematical Problem Solving Abilities. International Journal of Instruction, 12(4), 495-512. https://doi.org/10.29333/iji.2019.12432a 


\section{INTRODUCTION}

Based on basic competencies in the mathematics curriculum at the junior high school level, problem-solving is the main focus of mathematics learning in Indonesia (Kemdikbud, 2013). Until now, many researchers have tried to improve mathematical problem solving abilities in various ways. The approach currently recommended in the curriculum used in Indonesia is the scientific approach. The exploration approach has the same characteristics as the scientific approach. Exploration is the heart of a heuristic strategy, where the heuristic strategy itself is the steps needed by a problem solver to make progress in the problem being solved (Schoenfeld, 2014). Although exploration is considered as one of the suitable approaches to enhance students' mathematical problem-solving abilities, some research results show that the enhancement of mathematical problem-solving abilities of students who use the exploration approach still does not meet expectations (Fauziah, 2010; Sari, 2013; and Fitria et al., 2018). The results of previous studies indicate that the application of the exploration approach is presented in teaching materials that are printed on sheets of paper (Rohaeti, 2010; Anwar, 2012; Sari, 2015; Maryam et al., 2016; and Huda, 2017). Presentation of teaching materials in this way makes many students not interested in learning with an exploration approach (Sari, 2017). Presentation of teaching materials that printed on sheets of paper is considered as one of the causes of not optimal enhancement in mathematical problem-solving abilities with an exploration approach. Therefore, efforts need to be made so that students feel interested and enjoy learning with this approach. In this study, the effort is to present teaching materials in a cube by following the steps in the snow cube throwing (SCT) learning model.

\section{LITERATURE REVIEW}

\section{Snow Cube Throwing Learning Model}

Snow cube throwing is a development of the snowball throwing learning model. There are some differences between the two models of learning. The media used in snowball throwing is paper that is made to resemble a ball (Suprijono, 2009), while in snow cube throwing learning is a cube. The cubes were used in the study is a cube made of duplex paper and consists of six pieces that explore the questions with contextual issues by the number of sides of the cube. Another difference is, the problem presented in the snowball throwing learning model is made by the students, while in the snow cube throwing learning model, the problems presented are designed by the teacher. Math problems in this study consist of the issue of exploration with contextual problems. One of the similarities of both the learning model is in throwing activities. The snow-cube throwing learning model is intended to make students more interested and has much experience learning problems contextual exploration and all the students in the class are involved in learning activities in a pleasant atmosphere.

The implementation of this learning model allows students in one class meeting, students can learn a concept through various types of exploration problems that contextual. For example, if a class consists of 40 students, it takes 20 cubes for learning activities take place since each group consists of two people. If a concept is presented in 
five exploration problems, then there will be four cubes that have the same problem of exploration. Although the problem of exploration given to students is quite a lot, many students are not aware of it. The student's unconsciousness is caused because the five types of exploration problems presented are solved cooperatively. Besides, something that is not less important, during the learning process almost all students can be directly involved in learning activities. During the learning activities, students can practice many contextual questions in a pleasant atmosphere.

Students will compete with other groups to answer the questions as much as possible so that there was a positive competition in the classroom. Students and a group of their friends can help each other in answering questions that are in the cube. During this process it is expected that interaction between students and other students will occur by exchanging opinions to fill the problems contained in the given cube. In addition to their peers, learning with an SCT-Exploration learning model allows students to interact with all other students. The impact, students can learn from the results of other students' thoughts, or can provide corrections if there are errors in solving problems. Teachers in this study only served as a facilitator if students ask about the poorly understood (Sari, 2017).

\section{Problem Solving Ability}

Problem solving in mathematics is essentially a high-level thinking process. (Polya, 1945) Defines problem-solving as an effort to find a way out of difficulty, achieving a goal that is not immediately achievable. Furthermore, Polya stated that problem-solving is an intellectual activity to find solutions to problems faced by using the knowledge that has been learned. (CDC, 1982) Defines problem-solving as the process of applying knowledge that has been obtained previously in new and unusual situations. According to (Sumarmo, 1994) problem solving is an ability that must be achieved by students.

The importance of problem-solving skills has been presented by experts including (Bell, 1978) revealed some research results showed that problem-solving strategies that are generally learned in mathematics, in some instances, can be transferred and applied in other problem-solving situations. Mathematical problem solving can help students improve their analytical power and can help them apply that power to a variety of situations. The statement above indirectly reveals the importance of problem-solving skills in everyday life. Some opinions that connect the usefulness of problem-solving in aspects of daily life include: (Soedjadi, 1999) reveals that in mathematics the ability to solve problems for someone will help the success of that person in everyday life. Also, (Resnick, 1987) argues that problem-solving approaches contribute to the practical use of mathematics by helping people develop facilities so that they are adaptable when, for example, technology is broken. This ability can help people move to a new work environment today when most tend to be faced with some career changes during their tenure (Taplin, 2006). (Cockcroft, 1982) also advocates problem-solving as a tool for developing mathematical thinking as a tool for everyday life, saying that problemsolving abilities lie "at the heart of mathematics" because mathematics can be applied to a variety of unusual situations. 
The importance of problem-solving skills in learning mathematics and everyday life requires students to be a good problem solver. Some of the characteristics of a person are said to be good problem solvers revealed by (Scusa, 2008) who argue that good problem solvers when given unusual problems, they know what to do and can switch strategies because they have a list of simple problem-solving strategies. Good problem solvers must be able to set appropriate decision criteria, flexibly allocate their cognitive resources, review and evaluate previous decisions, implement alternative plans if necessary, and formulate plans at high levels of abstraction (Voss, 1989). (Simon et al., 1978), show that good problem solvers show an increase in planning, checking, and evaluating readiness.

Developing mathematical problem-solving skills is the primary goal of the mathematics curriculum at the School. Based on these objectives, a measurement of these capabilities is needed. The measurement of students' mathematical problem-solving abilities is done by giving problem-solving questions developed from the indicators of that ability. The indicators of problem-solving ability according to (NCTM, 2003) are: (1) Implementing and adapting various approaches and strategies to solve problems; (2) Resolve problems that arise in mathematics or in other contexts involving mathematics; (3) Building new mathematical knowledge through problem solving; and (4) Monitor and reflect on the mathematical problem solving process. The indicator is an indicator used to measure the mathematical problem-solving abilities of a prospective teacher. In addition, (Prabawanto, 2013) is the ability of students to solve mathematical problems by using appropriate strategies in several aspects, namely: (1) Resolving mathematically closed problems with the context in mathematics; (2) Resolving closed mathematical problems with contexts outside of mathematics; (3) Solve open mathematical problems with the context in mathematics; and (4) Solve open mathematical problems with contexts outside mathematics.

The problem-solving indicators used in measuring mathematical problem-solving abilities in this study are indicators expressed by (Sumarmo, 2016), namely (1) identifying the adequacy of data to solve problems; (2) Identifying strategies that can be used to solve mathematical models of contextual problems and given mathematical problems; (3) completing the mathematical model accompanied by reasons and (4) Checking the correctness of the solutions obtained. It is a consideration why the indicators used in this study are indicators expressed by (Sumarmo, 2016) because using these indicators can be known to the extent to which students' ability to solve problems.

\section{METHOD}

\section{Experimental Design}

This research was obtained using a quasi-experimental design with the non-equivalent control group design as follows: 


\begin{tabular}{lrr}
$O$ & $X$ & $O$ \\
\hline$O$ & $X_{2}$ & $O$ \\
\hdashline$O$ & & $O$
\end{tabular}

In such design, $\mathrm{X}=\mathrm{SCT}$-Exploration learning, $\mathrm{X}_{2}=$ Direct-Exploration Learning, and $\mathrm{O}=$ Test of MPSA.

\section{Participants}

This research was conducted in three schools with different characteristics. The purpose of grouping students into several school categories is based on each school having distinctive learning characteristics and student characteristics. Based on these objectives, it is possible that the application of the SCT-Exploration and Directexploration learning model will have a different impact on improving problem-solving abilities in each school category. The population was all eighth graders enrolled in public junior high schools in the city of Cimahi, Indonesia. The reason for choosing the population is because the average school in the city has not fully implemented scientific learning as suggested in the latest curriculum in Indonesia. So that, on average, students in the population almost have the same characteristics. Students are not familiar with scientific learning that requires students to be active in learning activities. This habit causes students to be less active and tend to wait for the transfer of knowledge from the teacher. There are 11 schools in total (there are 11 public junior high schools in the city of Cimahi).

Stratified random sampling and random sampling group techniques were used to select nine groups from 3 school categories. The three categories of schools in question are top, middle and lower school categories. The selection of these three categories of schools is based on input scores (national exam scores) when they enter junior high school level, meaning the top school category have better quality students than middle and lower school category. On the contrary, students in the lower school category have qualities below the middle and top school category. The first experiment class consists of 92 students; the second experiment class consists of 88 students; and the control class consists of 86 students. While the number of students in each group based on school categories, is presented as follows:

\begin{tabular}{llll}
\hline School & First Experiment & Second & Control \\
Categories & Class & Experiment Class & Class \\
\hline Top & 29 & 31 & 25 \\
Middle & 32 & 26 & 30 \\
Lower & 31 & 31 & 31 \\
\hline
\end{tabular}

\section{Instruments}

The instruments used were instruments of mathematical problem-solving ability tests and observation sheets. The first experimental group was given exploration teaching materials presented through the SCT learning model. The second experimental group 
was given exploration teaching materials presented in sheets of paper. Both experimental classes both obtain exploration-based teaching materials, but in SCTExploration the amount of teaching material given in one learning consists of five types of teaching materials, meaning that students can learn and complete one concept or problem in five different ways. Whereas in the direct-exploration class, the number of teaching-learning materials given in one learning is only one type. That is, students, learn and complete a concept or problem in one way. The control group is given expository learning without exploration teaching materials. The materials which were discussed while conducting the research was a circle and tangent circle.

\section{Techniques of Data Analysis}

Data on mathematical problem-solving abilities were collected using tests distributed before and after the learning process. The data which were processed was the scores of $\mathrm{N}$-gains. Data that has been collected, then analyzed using inferential and descriptive statistics. The statistical analysis used in this research is one-way ANOVA, t-test, MannWhitney test, dan Kruskal-Wallis test with significance level 0.05. There are two research hypotheses that will be tested as follows:

1. Is the mathematical problem-solving ability of students who get SCT-Exploration learning better than the mathematical problem-solving abilities of students who get Direct-Exploration and expository learning seen from the whole student?

2. Is the mathematical problem-solving ability of students who get SCT-Exploration learning better than the mathematical problem-solving abilities of students who get Direct-Exploration and expository learning seen from each school category?

\section{FINDINGS}

\section{Descriptive Statistics of Mathematical Problem-Solving Abilities (MPSA) Regarding All Students}

The data used in this section is a combination of data on students' mathematical problem-solving abilities in the upper, middle and lower categories. A description of the mean, standard deviation and number of students regarding all students is presented in Table 1.

Table 1

Pretest and Post-Test of MPSA

\begin{tabular}{lllllll}
\hline \multirow{2}{*}{ Statistic } & \multicolumn{2}{l}{ SCT-Exploration Learning } & \multicolumn{2}{c}{ Direct-Exploration Learning } & \multicolumn{2}{c}{ Expository Learning } \\
\cline { 2 - 6 } & Pre-test & Post-test & Pre-test & Post-test & Pre-test & Post-test \\
\hline Mean & 8,20 & 46,55 & 2,86 & 30,42 & 8,72 & 28,66 \\
SD & 9,97 & 20,61 & 5,20 & 15,44 & 7,56 & 18,49 \\
N & 92 & 92 & 88 & 88 & 86 & 86 \\
\hline
\end{tabular}

The mean score of the expository group before learning is higher than the mean score of the SCT-Exploration and expository groups, while the mean score of the DirectExploration group before learning is the lowest. However, the enhancement in the mean score of the SCT-Exploration group after learning is higher when compared to the enhancement in the mean score of the Direct-Exploration and expository groups. 
Although the pre-test results from expository groups were the highest compared to the other two groups, the enhancement in the mean scores of the expository group was lower than the other two groups. The enhancement in the mean score of the SCTExploration, Direct-Exploration and expository groups were 38.35, 27.56 and 18.24 respectively.

The Average normalized gain for each MPSA aspect of the three learning groups is presented in Table 2.

Table 2

Description of Average Normalized Gain from Aspects in MPSA

\begin{tabular}{lllll}
\hline \multirow{2}{*}{ Learning } & \multicolumn{3}{l}{ Aspects in MPSA } & \\
\cline { 2 - 5 } & Understanding & Make a & Solve the & Looking \\
& Problems & Plan & Problem & Back \\
\hline SCT-Exploration & 0,49 & 0,50 & 0,32 & 0,27 \\
Direct-Exploration & 0,36 & 0,23 & 0,29 & 0,03 \\
Expository & 0,27 & 0,18 & 0,23 & 0,07 \\
\hline
\end{tabular}

The differences in the mathematical problem-solving abilities among the students exposed to SCT-Exploration learning, Direct-Exploration and those exposed to expository learning are presented in Table 3.

Table 3

Tests of Difference between Three Average of MPSA Normalized Gain on Total Students

\begin{tabular}{llllll}
\hline Learning & $\begin{array}{l}\text { The Average } \\
\text { Normalized Gain }\end{array}$ & $\begin{array}{l}\text { Chi- } \\
\text { Square }\end{array}$ & df & Sig. & Conclusion \\
\cline { 1 - 2 } SCT-Exploration (E1) & 0,42 & 49,624 & 0,000 & $\mathrm{H}_{\mathrm{o}}$ rejected \\
\cline { 1 - 2 } Direct-Exploration (E2) & 0,28 & & 2 & & \\
\cline { 1 - 5 } Expository (E3) & 0,22 & & & \\
\hline
\end{tabular}

the results of the data analysis concluded that Ho was rejected, indicating that there are significant differences in enhancement the MPSA among the student exposed the SCTExploration learning, Direct-Exploration and those exposed the expository learning.

Furthermore, post hoc tests are needed to confirm where the differences occurred between groups. The results of the post-hoc test of MPSA enhancement between the two learning are presented in Table 4.

Table 4

Post Hoc Tests of MPSA enhancement between two Learning

\begin{tabular}{lllll}
\hline Comparison & Mean Difference & Mann-Whitney U & Sig. (2-tailed) & Conclusion \\
\hline E1 vs E2 & $0,134^{*}$ & 2539,500 & 0,000 & $\mathrm{H}_{\mathrm{o}}$ rejected \\
E1 vs E3 & $0,202^{*}$ & 1720.000 & 0,000 & $\mathrm{H}_{\mathrm{o}}$ rejected \\
E2 vs E3 & $0,068^{*}$ & 2545,500 & 0,000 & $\mathrm{H}_{\mathrm{o}}$ rejected \\
\hline
\end{tabular}

Enhancement students' MPSA exposed the SCT-Exploration learning were significantly better than students' MPSA exposed Direct-Exploration and expository learning. Therefore, it can be assumed that SCT-Exploration learning has a more significant effect 
in enhancement students' MPSA compared to direct-exploration and expository learning.

The differences in the mathematical problem-solving abilities among the students exposed to SCT-Exploration learning, Direct-Exploration and those exposed to expository learning by school category are presented in Table 5 .

Table 5

Tests of Difference between Three Average of MPSA Normalized Gain by School Category

\begin{tabular}{lllll}
\hline School Category & Comparison & Chi-Square & Sig. & Conclusion \\
\hline Top & E1 vs E2 vs E3 & 14,575 & 0,001 & $\mathrm{H}_{\mathrm{o}}$ rejected \\
Middle & E1 vs E2 vs E3 & 32,759 & 0,000 & $\mathrm{H}_{\mathrm{o}}$ rejected \\
Lower & E1 vs E2 vs E3 & 16,556 & 0,000 & $\mathrm{H}_{\mathrm{o}}$ rejected \\
\hline
\end{tabular}

The results of the data analysis concluded that Ho was rejected, indicating that there are significant differences in enhancement the MPSA among the student exposed the SCTExploration learning, Direct-Exploration and those exposed the expository learning in each school category.

Furthermore, post hoc tests are needed to confirm where the differences occurred between groups in each school category. The results of the post hoc test of MPSA enhancement between the two learning are presented in Table 6.

Table 6

Post Hoc Tests of MPSA enhancement between two Learning in Each School Category

\begin{tabular}{|c|c|c|c|c|c|}
\hline $\begin{array}{l}\text { School } \\
\text { Category }\end{array}$ & Comparison & Mean Difference & $\mathrm{t}$ & Sig. (2-tailed) & Conclusion \\
\hline \multirow[t]{4}{*}{ Top } & E1 vs E2 & $0,136^{*}$ & 4,196 & 0,000 & $\mathrm{H}_{\mathrm{o}}$ rejected \\
\hline & Comparison & Mean Difference & Mann-Whitney U & Sig. (2-tailed) & Conclusion \\
\hline & E1 vs E3 & 0,107 & 191,500 & 0,003 & $\mathrm{H}_{\mathrm{o}}$ rejected \\
\hline & E2 vs E3 & $-0,029$ & 340,500 & 0,438 & $\mathrm{H}_{\mathrm{o}}$ accepted \\
\hline \multirow[t]{3}{*}{ Middle } & E1 vs E2 & $0,199^{*}$ & 178,000 & 0,000 & $\mathrm{H}_{\mathrm{o}}$ rejected \\
\hline & E1 vs E3 & $0,328^{*}$ & 118,500 & 0,000 & $\mathrm{H}_{\mathrm{o}}$ rejected \\
\hline & E2 vs E3 & $0,128^{*}$ & 208,500 & 0,003 & $\mathrm{H}_{\mathrm{o}}$ rejected \\
\hline \multirow[t]{3}{*}{ Lower } & E1 vs E2 & 0,043 & 422,000 & 0,410 & $\mathrm{H}_{\mathrm{o}}$ accepted \\
\hline & E1 vs E3 & $0,156^{*}$ & 226,500 & 0,000 & $\mathrm{H}_{\mathrm{o}}$ rejected \\
\hline & E2 vs E3 & $0,113^{*}$ & 256,000 & 0,002 & $\mathrm{H}_{\mathrm{o}}$ rejected \\
\hline
\end{tabular}

Enhanced MPSA of students exposed the SCT-Exploration learning were significantly better than enhanced MPSA of students exposed Direct-Exploration and expository learning in upper and middle category school. Therefore, it can be assumed that SCTExploration learning has a more significant effect in enhancement students' MPSA compared to the direct-exploration and expository learning in upper and middle category school. Whereas in the lower category school, enhanced MPSA of students exposed the SCT-Exploration learning and Direct-Exploration learning were significantly better than enhanced MPSA of students exposed expository learning. Therefore, it can be assumed that the SCT-Exploration learning and Direct-Exploration learning has more significant effect in enhancement students' MPSA compared to the expository learning in the lower category school. 
The differences in the mathematical problem-solving abilities among the students who are exposed to the SCT-Exploration learning in each school category are presented in Table 7.

Table 7

Tests of Difference between Three Average of MPSA Normalized Gain on SCTExploration Group by School Category

\begin{tabular}{|c|c|c|c|c|c|}
\hline $\begin{array}{l}\text { SCT-Exploration Learning } \\
\text { by School Category }\end{array}$ & $\begin{array}{l}\text { The Average } \\
\text { Normalized Gain }\end{array}$ & $\begin{array}{l}\text { Chi- } \\
\text { Square }\end{array}$ & $\mathrm{df}$ & Sig. & Conclusion \\
\hline Top (T) & 0,35 & \multirow{3}{*}{24,245} & \multirow{3}{*}{2} & \multirow{3}{*}{0,000} & \multirow{3}{*}{$\mathrm{H}_{\mathrm{o}}$ rejected } \\
\hline Middle (M) & 0,57 & & & & \\
\hline Lower (L) & 0,33 & & & & \\
\hline
\end{tabular}

Furthermore, post hoc tests are needed to confirm where the differences occurred between groups SCT-Exploration by school category. The results of the post-hoc test of MPSA enhancement between the two groups are presented in Table 8 .

Table 8

Post Hoc Tests of MPSA enhancement between two SCT-Exploration Learning by School Category

\begin{tabular}{lllll}
\hline Comparison & Mean Difference & Mann-Whitney U & Sig. (2-tailed) & Conclusion \\
\hline T vs M & $-0,22$ & 177,500 & 0,000 & $\mathrm{H}_{\mathrm{o}}$ ditolak \\
\hline M vs L & 0,24 & 185,500 & 0,000 & $\mathrm{H}_{\mathrm{o}}$ ditolak \\
\hline Comparison & Mean Difference & $\mathrm{T}$ & Sig. (2-tailed) & Conclusion \\
\hline T vs L & 0.02 & 0,384 & 0,703 & $\mathrm{H}_{\mathrm{o}}$ diterima \\
\hline
\end{tabular}

Enhancement students' MPSA exposed the SCT-Exploration learning in middle category school were significantly better than students' MPSA exposed SCTExploration learning in upper and lower category school. Therefore, it can be assumed that SCT-Exploration learning is better suited to the middle category school.

\section{DISCUSSION AND CONCLUSION}

In general, the results of the study show that students who learn using SCTBE learning models get better MPSA compared Direct-Exploration and expository learning regarding all students. In addition to being reviewed all students, students who learn with SCT-Exploration learning also get better enhancements than students who learn with Direct-Exploration, and expository learning is seen from the four aspects of problem-solving.

Enhancement in understanding the problem, making plans and solving problems aspects in the SCT-exploration group was better than the other two groups. The enhancement in students' understanding was caused because students had practiced a lot to solve many problems through exploration activities. Direct-exploration learning itself is not as expected because the method of presenting teaching materials in the learning is not very interesting to students.

Judging by all aspects of problem-solving, enhancing the scores of SCT-Exploration group students is included in the medium category except in the aspect of looking back. 
Although the SCT-Exploration group gained a low enhancement in aspects of looking back, the enhancement in the MPSA score of the SCT-Exploration group regarding looking back looked much better than the group that gained Direct-Exploration and expository learning. In the aspect of looking back, these two groups had a very low enhancement. Factors of interest are suspected as the cause of low ability. (Lester et al., 1989) Argue that lack of interest inhibits their development as problem solvers. Because of lack of interest, they rarely bother checking their work, considering the reasonableness of their answers, or doing good monitoring activities.

Based on the theory, students who obtain SCT-Exploration learning should have a high ability in the aspect of looking back. However, the results of observations on students' answers on the cube, most students have not been able to correct the wrong answers from their friends. Some students tend not to re-check their answers before answering the next problem. In fact, in SCT-Exploration learning, students are encouraged to look back at the answers of other groups before moving on to the next problem. These symptoms are consistent with what (Kantowski, 1977) said that students rarely look back, or review solutions to a problem. Several studies on the profile of students' mathematical problem-solving abilities in Indonesia indicate that students have not been able to check the results they have obtained (Vendiagrys \& Junaedi, 2015; Ulya, 2016; Novianti, 2017). Instead, once a solution is submitted, students tend to lose all interest in the problem and move on to other tasks. (Bloom \& Broder, 1950) Provide another perspective on this. They noted how problem-solving involves a cycle of tension and relaxation; Generally, problem solvers will feel relaxed when they have obtained a solution. The Relaxation can occur even if the solution is incorrect. Research results (Novianti, 2017) show that, students rarely check answers that have been obtained if they are sure they can answer the problem. Instead, they would check back the answer if they are not sure of the answers obtained.

Not as expected, the ability to look back in SCT-Exploration learning is not only caused by the lack of effective implementation of learning but as Kroll said (Lester et al., 1989). We believe that students can be taught to monitor effectively, but progress may be somewhat slow, especially for students who have not mastered basic math skills or who have a tendency to be preoccupied with procedural importance to override relational and organisational problems. That means that to teach the skills of checking solutions will be less optimal if students have not mastered good basic math skills.

Based on the results of observation, students who obtained SCT-Exploration learning looked more enthusiastic during the learning process than students who obtained DirectExploration and expository learning. Although in practice the SCT-Exploration and Direct-Exploration group obtained the same teaching materials, the students' responses during learning showed different things. Students of the Direct-Exploration group stated that they had difficulty filling out the instructional material provided. It is different from the SCT-Exploration group, with the same teaching materials they look enthusiastic and able to fill all the teaching materials provided. Observation results were also supported by students' statements stating that they felt more excited when learning by using a cube. 
Unlike the SCT-Exploration group, the Direct-Exploration group showed the opposite attitude.

The results of the open questionnaire given to the Direct-Exploration group indicate that students experience confusion in filling out teaching materials because they were not taught beforehand. The students' answer shows that students cannot study independently. The results showed that there was a positive and significant correlation between independent learning attitudes and learning achievement. This result means that the better the learning independence of students, the better their learning achievement will be. Independent learning attitudes contribute to $40.96 \%$ of student learning achievements (Saefullah et al., 2017). This is why the Direct-Exploration group gained a lower enhancement than the SCT-Exploration group. In SCT-Exploration learning students become more independent in learning; this is shown from the results of questionnaires regarding student responses during the learning process. SCTExploration group students admitted that they began to get used to learning independently in solving the problems that were given. The activity of throwing a cube in SCT-Exploration learning is the main attraction for students. The activity of throwing a cube is considered a fun activity, so students can learn while playing. Even though in one study students must fill in different types of teaching materials, but because of the growing independence in learning, students do not complain about it. On the other hand, a different response appears from the Direct-Exploration group who complained that even though only one type of teaching material was given.

Another thing that causes SCT-Exploration students to be more superior compared to Direct-Exploration students is thought to be due to a lack of student learning independence. Learning independence must be grown in students so that the learning process can run optimally. (Cotič, \& Zuljan, 2009) Say that quality mathematics teaching must give students two things: challenges and feelings of success if they have accomplished something. This attitude allows them to grow independently gradually.

Based on the results of observations and interviews, not all students in DirectExploration learning are actively involved in learning activities. This result causes the implementation of learning through exploration activities to be less optimal. The ineffectiveness of learning through an exploration approach is due to the lack of independence of students during learning activities. Learning independence factor is very influential in students' attitudes during learning. Students with low learning independence tend to complain if they are required to learn in gaining knowledge actively. This complaint is because students are more accustomed to obtaining knowledge directly from the teacher. The statement above, similar to (Schoenfeld, 2009) stated that students usually could not expect to understand mathematics; they only hope to memorize it and apply what they have learned mechanically and without understanding.

Given the characteristics of students in three school categories, the results of the study showed that the enhancement in MPSA of students who received SCT-Exploration learning was superior to students who received expository learning in each school category. Also, in middle and lower category schools, Direct-Exploration learning is 
superior to expository learning. Direct-Exploration group superiority compared to expository classes is because the characteristics of students in middle and lower category schools are more independent than those in Direct-Exploration classes in the upper category schools. This characteristic of students were shown from the results of an open questionnaire from students which showed that less than half of the students were not fully aware of the material provided in the teaching material. Even some students stated that although initially, they were not happy to study independently, over time they understood the material provided. That statement indicates that gradually, some students show a positive attitude towards Direct-Exploration learning.

The presentation of teaching materials presented in ordinary worksheets is also allegedly not to raise students' interest in learning. Interest and pleasure, both influence the level of student involvement in learning and the depth of understanding that will be obtained (Schiefele, 2009). The results of the research conducted (Gunuc, 2014) revealed that there was a significant relationship between student academic achievement and student involvement, especially in the dimensions of cognitive involvement, behavioral involvement and sense of belonging. According to (Stovall, 2003), student involvement does not only include the time students spend on assignments but also their willingness to do so to take part in activities. The attitude of students who are not enthusiastic during the learning process causes students not to be able to optimize their ability to fill in the teaching materials provided. (Borkowski, Weyhing \& Carr, 1988) in his research more related failure due to lack of effort than lack of ability.

Unlike the Direct-Exploration group, the teaching materials in SCT-Exploration learning model are presented in cubes. Presentation of teaching materials in a unique way like this makes almost all students involved in learning activities. Behavioral involvement includes student participation in the academic field, their business, their presence in the classroom and their participation in the classroom (Gunuc \& Kuzu, 2014). Cognitive involvement refers to students who invest in their learning, which determines the goals of their needs and who enjoy mental difficulties (Gunuc \& Kuzu, 2014). Researchers have found that student involvement is a predictor of student achievement and behavior in school (Voelkl, 1995). Student involvement in schools tends to get higher test scores (Goodenow, 1993) and (Roderick \& Engel, 2001). If students have shown participation in the class, then the student will try to bring out all his abilities, so that the results can be better.

Also, in the implementation of SCT-Exploration learning students compete with other friends to fill as many parts of the cube as possible. Students who can answer problems on the sides of the cube will get points. Students who get the most points will get rewards. Race and Brown argue that behaviorist schools believe that learning occurs through the stimulus, response, and appreciation. The stimulus of the teacher as input and learned behavior is the output (Lester et al., 1989). In SCT-Exploration learning, a stimulus is obtained from the competition to collect as many points as possible. Competition is also a part of our lives and is often used to stimulate learning motivation and learning achievement (Lin et al., 2017). This has implications for the response of students who showed an eager attitude to compete, as well as enthusiastic in solving 
problems on the cube. Reward in SCT-Exploration learning is a form of appreciation for students or groups who can get the most points. By giving an appreciation, it is hoped that other students will also be motivated and enthusiastic in the learning process.

The results showed that the average enhancement in MPSA of the SCT-Exploration and Direct-Exploration group was better than the expository group. Learning in groups seems to affect enhancing MPSA. The results of the study by Kim, Lindquist \& Kang (2016) show that group-based learning is an effective teaching strategy for enhancing problem-solving abilities. In SCT learning, students' exploration is grouped with their peers, and in Direct-Exploration learning, one group consists of five students. However, the grouping of students in SCT-Exploration learning was felt to be more effective than the grouping of students in Direct-Exploration learning because based on the results of the questionnaire, the students of the Direct-Exploration group admitted that some of their friends did not participate in the discussion activities. Lack of student involvement can be minimised by reducing the number of members in one group as in SCTExploration learning.

The enhancement in MPSA groups that obtain expository learning is lower than the other two groups because, in this learning, students are more passive in receiving learning material. Students only watch how the teacher gives examples of questions without being directly involved in solving them independently. "What I hear, I forget, what I see, I remember, what I do, I understand." Xunzi in (Bennett, 2007). This Confucius scholar stated that actual learning is when the hearing is not as good as seeing, seeing is not as good as experience and true learning is only proven when experience produces an action. This explains that if students are directly involved in solving problems, students can not only remember the work procedures but also understand how to step up in each problem-solving process.

Although the mathematical problem-solving ability of the SCT-Exploration group students is better than the other two learning, the enhancement is still classified as the medium category. One of the factors suspected to be the cause is due to the difficulty of the mathematical problem solving given. The results of interviews with students of the SCT-Exploration group showed that most students stated that the questions given were difficult for them when compared to the questions commonly given by their respective teachers.

The results of the data analysis also showed that the MPSA students who obtained SCTExploration learning in the upper category schools were no different from SCTExploration students in the lower category schools. In other words, MPSA students who obtained SCT-Exploration learning in middle category schools were better than SCTExploration students in upper and lower category schools. Seen based on their characteristics, SCT-Exploration students in middle and lower category schools tend to be more active than SCT-Exploration students in the upper category schools. This can be seen from the results of observations that have been carried out, almost in every meeting the upper category students rarely ask questions when facing difficulties in solving problems. They prefer to make mistakes in filling instructional materials rather than having to ask the teacher. 
In contrast to students from middle and lower category schools, almost all students always ask questions when they face difficulties in solving problems. In this class, circumstances tend to be noisy but remain productive. (Nelson et al., 1983) Reveal two reasons that cause students not to ask questions when facing difficulties. First, students may not realize that they cannot solve problems. Such unconsciousness, may often occur among students who see other people solving problems; they think that they understand how to deal with it, but do not try to solve it themselves. Second, even when students realise that they cannot solve problems, they may not ask for help because they are afraid of appearing incompetent. They believe that asking for help is not allowed or sanctioned, has experienced negative reinforcement before, asks but does not get a response, believe that it is not other people in their group have sufficient skills to help or do not have the motivation to solve problems.

It seems that the characteristics of active students also support the successful implementation of SCT-Exploration learning in the classroom so that an enhancement in the SCT-Exploration group in the middle category schools has a significant enhancement compared to the other two groups. Students who always participate and raise their hands are people who benefit from high-level problems prepared by teachers (Himmele, \& Himmele, 2017). According to (Mihardi, 2015), learning effectiveness occurs because students actively learn to find and find their answers to problems, not only passively receive information from the teacher. The enhancement in the SCTExploration group in the lower category schools does not seem to exceed SCTExploration students in the middle category schools despite having the same characteristics, the factors that cause differences are the students' initial ability before learning.

Also, the SCT-Exploration group in the top school's category has begun to look bored at the fourth meeting. They expect more "serious" learning without the elements of play. Students expect the teacher to be able to explain the material to be conveyed directly and students practice solving mathematical problems given by the teacher by following the examples. Students with these characteristics do not want to bother acquiring knowledge through exploration activities. They tend to expect to obtain knowledge directly from the teacher.

Although the SCT-Exploration group in the lower category schools had characteristics similar to the SCT-Exploration group in the middle category school, the enhancement in the MPSA of this group was still under the SCT-Exploration group in the middle category school. The low initial math knowledge of the SCT-Exploration group in low category schools led to an under-optimal enhancement in the MPSA score. The low initial mathematical knowledge of the lower category schools resulted in an enhancement in the MPSA score not as high as the SCT-Exploration group in the middle category school. However, the results of the analysis showed that the MPSA of the SCTExploration group in the upper and lower category schools did not show significant differences. This shows that the quality of the MPSA enhancement in the SCTExploration group in the upper and lower category schools is not much different considering that the primary mathematical abilities of the SCT-Exploration group in the 
upper category schools were higher than the SCT-Exploration group in the lower category schools. That is, SCT-Exploration learning is more suitable for groups of students who are active and have excellent math skills. Based on the results and discussion, we can draw on the conclusion that the results of the study show that the different ways of presenting teaching materials can have an impact on enhancing problem-solving abilities better.

\section{ACKNOWLEDGEMENT}

We gratefully express our gratitude to DRPM Directorate General of Reinforcement Risbang through Research Program of Doctoral Dissertation, which is kindly funding the research reported in this paper.

\section{REFERENCES}

Anwar, V. N. (2012). Pengaruh pembelajaran eksploratif terhadap peningkatan kemampuan penalaran, kemampuan komunikasi, dan karakter matematis siswa sekolah menengah pertama. (Unpublished master thesis). Universitas Pendidikan Indonesia, Indonesia.

Bell, F. H. (1978). Teaching and learning mathematics: Iin secondary schools. Dubuque, Iowa : Wm. C. Brown.

Bennett, K. (September 12, 2007). What I hear I forget, what I see I remember, what I do I understand. The Phrase Finder. Retrieved from https://www.phrases.org.uk/bulletin_board/55/messages/669.html.

Bloom, B. S., \& Broder, L. J. (1950). Problem-solving processes of college students. Chicago: University of Chicago Press.

Borkowski, J. G., Weyhing, R. S., \& Carr, M. (1988). Effects of attributional retraining on strategy-based reading comprehension in learning-disabled students. Journal of Educational Psychology, 80(1), 46- 53. http://dx.doi.org/10.1037/0022-0663.80.1.46.

Cockcroft, W. H. (1982). Mathematics counts. London: HM Stationery Office.

Cotič, M., \& Zuljan, M. V. (2009). Problem-based instruction in mathematics and its impact on the cognitive results of the students and on affective-motivational aspects. Educational studies, 35(3), 297-310.

Curriculum Development Centre (1982). Australian mathematics education program: a statement of basic mathematical skills and concepts. Canberra: CDC.

Fauziah, A. (2010). Peningkatan kemampuan pemahaman dan pemecahan masalah matematik siswa smp melalui strategi react. In Forum kependidikan, 30(1), 1-13.

Fitria, N. F. N., Hidayani, N., Hendriana, H., \& Amelia, R. (2018). Analisis kemampuan pemecahan masalah matematik siswa smp dengan materi segitiga dan segiempat. Edumatica Jurnal Pendidikan Matematika, 8(1), 49-57. 
Goodenow, C. (1993). Classroom belonging among early adolescent students: relationships to motivation and achievement. The J. of Early Adolescence, 13(1), 21-43.

Gunuc, S. (2014). The relationships between student engagement and their academic achievement. International Journal on New Trends in Education and Their Implications, 5(4), 216-231.

Günüç, S., \& Kuzu, A. (2014). Factors influencing student engagement and the role of technology in student engagement in higher education: campus-class-technology theory. Turkish Online Journal of Qualitative Inquiry, 5(4), 86-113.

Himmele, P., \& Himmele, W. (2017). Total participation techniques: Making every student an active learner. ASCD.

Huda, M. (2017). Meningkatkan kemampuan memecahkan masalah matematis siswa man babat melalui strategi pembelajaran eksploratif. In PRISMA, Prosiding Seminar Nasional Matematika, 114-123.

Kantowski, M. G. (1977). Processes involved in mathematical problem solving. Journal for Research in Mathematics Education, 8(3),163-180.

Kemdikbud. (2013). Kompetensi inti dan kompetensi dasar matematika smp/mts. Retrieved from https://goeroendeso.files.wordpress.com/2017/12/lampiran-15-ki-dankd-k-13-smp-mts-matematika.pdf.

Kim, H. R., Song, Y., Lindquist, R., \& Kang, H. Y. (2016). Effects of team-based learning on problem-solving, knowledge and clinical performance of Korean nursing students. Nurse Education Today, 38, 115-118.

Lester, F. K., Garofalo, J., \& Kroll, D. L. (1989). Self-confidence, interest, beliefs, and metacognition: Key influences on problem-solving behavior. In D. B. McLeod et all (Eds.), Affect and mathematical problem solving (pp. 75-88). Springer, New York, NY.

Lin, C. H., Huang, S. H., Shih, J. L., Covaci, A., \& Ghinea, G. (2017). Game-based learning effectiveness and motivation study between competitive and cooperative modes. In Advanced Learning Technologies (ICALT), 2017 IEEE 17th International Conference on, 123-127. IEEE.

Maryam, S., \& Aeni, A. N. (2016). Pendekatan eksploratif untuk meningkatkan kemampuan representasi matematis dan kepercayaan diri siswa. Jurnal Pena Ilmiah, 1(1), 551-560.

Mihardi, S. (2015). Enhanced characters and student learning outcomes through development of character education based general physics learning model. Education, 6(21), 162-171.

National Council of Teachers of Mathematics. (2003). NCTM program standards. programs for initial preparation of mathematics teachers. standards for secondary mathematics teachers. Retrieved from http://www.nctm.org/ uploadedFiles/Math_Standards/. 
Nelson-Le Gall, S. Gumerman \& Scott-Jones, D. (1983). Instrumental help-seeking and everyday problem-solving: a developmental perspective. New Directions in Helping, 2, 265-283.

Novianti, D. E. (2017). Profil pemecahan masalah matematika dalam menyelesaikan permasalahan pemrograman linear ditinjau dari kemampuan komunikasi matematis mahasiswa. Jurnal Ilmiah Pendidikan Matematika, 6(1), 53-59.

Polya, G. (1945). How to solve it: A new aspect of mathematical model. Princeton, New Jersey.

Prabawanto, S. (2013). Peningkatan kemampuan pemecahan masalah, komunikasi, dan self-efficacy matematis mahasiswa melalui pembelajaran dengan pendekatan metacognitive scaffolding (Unpublished doctoral dissertation). Universitas Pendidikan Indonesia, Indonesia.

Resnick, L. B. (1987). Education and learning to think. National Academies.

Roderick, M., \& Engel, M. (2001). The grasshopper and the ant: Motivational responses of low-achieving students to high-stakes testing. Educational Evaluation and Policy Analysis, 23(3), 197-227.

Rohaeti, E. E. (2008). Pembelajaran dengan pendekatan eksplorasi untuk mengembangkan kemampuan berfikir kritis dan kreatif matematika siswa smp (Unpublished doctoral dissertation). Universitas Pendidikan Indonesia, Indonesia.

Saefullah, A., Siahaan, P., \& Sari, I. M. (2017). Retracted article: The correlation of learning independence attitudes and student's learning achievement on physics learning based-portfolio. Jurnal Penelitian dan Pembelajaran IPA, 3(1), 74-83.

Sari, N. M. (2015). Meningkatkan kemampuan pemecahan masalah matematis dengan metode eksplorasi. Alphamath, 1(1).

Sari, N. M. (2017). The effectiveness of snow cube throwing learning model based on exploration. In AIP Conference Proceedings 1868(1). AIP Publishing.

Schoenfeld, A. H. (2014). Mathematical problem solving. Elsevier.

Schoenfeld, A. H. (2009). Learning to think mathematically: problem solving, metacognition, and sense-making in mathematics. Colección Digital Eudoxus, 7.

Schiefele, U. (2009). Situational and individual interest. Handbook of motivation at school, 197-222.

Scusa, T. (2008) Five processes of mathematical thinking. Summative projects for ma degree, 38. Retrieved from http://digitalcommons.unl.edu/ mathmidsummative/38.

Simon, H. A., Dantzig, G. B., Hogarth, R., Plott, C. R., Raiffa, H., Schelling, T. C., .. \& Winter, S. (1987). Decision making and problem solving. Interfaces, 17(5), 11-31.

Soedjadi, R. (1999). Kiat pendidikan matematika di indonesia. Jakarta: Depdikbud. 
Suprijono, A. (2009). Cooperative learning teori \& aplikasi paikem. Yogyakarta: Pustaka Pelajar.

Stovall, I. (2003). Engagement and on-line learning [electronic version]. UIS community of practice for e-learning. Retrieved from http://otel.uis.edu/copel/EngagementandOnlineLearning.ppt.

Sumarmo, U. (1994). Suatu alternatif pengajaran untuk meningkatkan kemampuan pemecahan masalah pada guru dan siswa di kodya bandung. IKIP Bandung Research Report: Not Published.

Sumarmo, U. (2016). Pedoman pemberian skor pada beragam tes kemampuan matematik. Retrieved from https://utari-sumarmo. dosen. stkipsiliwangi. ac. id/files /2016/05/Pedoman-Pemberian-Skor-Tes-Kemampuan-Berpikir-Matematik-dan-MPP 2016-1.pdfopen_in_new.

Taplin, M. (2006). Mathematics through problem solving. Retrieved from http://tvslvslearningforum.org/pdf/classroom_practices.pdf.

Ulya, H. (2016). Profil kemampuan pemecahan masalah siswa bermotivasi belajar tinggi berdasarkan ideal problem solving. Jurnal Konseling Gusjigang, 2(1), 90-96.

Vendiagrys, L., \& Junaedi, I. (2015). Analisis kemampuan pemecahan masalah matematika soal setipe timss berdasarkan gaya kognitif siswa pada pembelajaran model problem based learning. Unnes J. of Mathematics Education Research, 4(1), 34-41.

Voelkl, K. E. (1995). School warmth, student participation, and achievement. The Journal of Experimental Education, 63(2), 127-138.

Voss, J. F. (1989). Problem solving and the educational process. In A. Lesgold \& R. Glaser (Eds.), Foundations for a psychology of education (pp. 251-294). Hillsdale, NJ, US: Lawrence Erlbaum Associates, Inc. 